\title{
Asas Kepastian Hukum dalam Penyelengaraan Perpajakan di Indonesia
}

\author{
Iyan Nasriyan \\ Fakultas Hukum, Universitas Kuningan, Indonesia \\ Email : iyannasriyan@gmail.com
}

\begin{abstract}
Law is a regulation made by an authorized institution to regulate public order. A realistic approach to law is legal certainty. The purpose of this research is to find out the principle of legal certainty that plays a role in the administration of taxation in Indonesia. The research method used by the author is Normative Juridical, with data collection tools through literature study. The results showed that legal certainty is "sicherkeit des Rechts selbst" (certainty about the law itself). A law must be certain because with certain things it can be used as a measure of truth and for the achievement of legal objectives that demand peace, tranquility, welfare and order in society as well as legal certainty must be able to guarantee public welfare and guarantee justice for the community.
\end{abstract}

Keywords: Principle of Legal Certainty, taxation

\begin{abstract}
Abstrak
Hukum adalah suatu peraturan yang dibuat oleh lembaga yang berwenang untuk mengatur ketertiban masyarakat. Tujuan hukum yang mendekati realistis adalah kepastian hukum. Tujuan dalam penelitian ini adalah untuk mengetahui Asas kepastian hukum berperan dalam penyelenggaraan perpajakan di Indonesia. Metode penelitian yang digunakan oleh penulis adalah Yuridis Normatif, dengan alat pengumpul data melalui studi kepustakaan. Hasil penelitian menunjukan bahwa Kepastian hukum adalah "sicherkeit des Rechts selbst" (kepastian tentang hukum itu sendiri). Suatu hukum harus pasti karena dengan hal yang bersifat pasti dapat dijadikan ukuran kebenaran dan demi tercapainya tujuan hukum yang menuntut kedamaian, ketentraman, kesejahteraan dan ketertiban dalam masyarakat serta kepastian hukum harus dapat menjadi jaminan kesejahteraan umum dan jaminan keadilan bagi masyarakat.
\end{abstract}

Kata Kunci : Asas Kepastian Hukum, perpajakan

\section{PENDAHULUAN}

Bila kita memahami bunyi pasal 1 ayat 1 KUHP : Pertama, Tentang konfrontasi antara kepastian hukum dan keadilan sosial bagi orang atau barang siapa yang ingin menegakkan atau menjalankan undang-undang pidana, karena pasal 1 ayat 1 merupakan tiang-tiang dari hukum pidana. Pertentangan tersebut terjadi karena pasal 1 ayat 1 menghendaki adanya peraturan sebelum tindakan yang dianggap melanggar hukum itu terjadi hal ini menunjukkan tentang kepastian hukum dan mengesampingkan keadilan, hal itu disebabkan karena proses hukum pidana bermuara pada penjatuhan pidana. Sungguh kiranya hal ini tidak akan mencerminkan nilai-nilai keadilan bagi korban apabila pemidanaan itu saat terpidana tersebut melakukan perbuatan, akan tetapi aturan hukumnya yang mengancam perbuatannya belum ada. Pasal 1 ayat 1 lebih mementingkan kepastian hukum diatas keeadilan sosial, Jika kita berpegang secara teguh terhadap asas legalitas sebagaimana yang tercantum dalam Pasal 1 ayat (1) KUHP maka pertanyaan ini tak akan muncul, karena konsekuensinya sudah jelas, yaitu terhadap perbuatan yang demikian tak akan ada hukumannya dan pelakunya bebas dari jerat hukum. Pertanyaan ini menjadi lebih tajam jika dikaitkan dengan persoalan keadilan bagi para korban kejahatan, apakah hukum akan mengabaikan salah satu fungsinya dengan membiarkan ketidakadilan bagi para korban dengan menguntungkan pelaku kejahatan. Perlu diingat hal itu akan mencederai keadilan hukum yang ada di masyarakat khususnya hukum 
Logika : Journal of Multidisciplinary Studies, p-ISSN 2085-9970. e-ISSN 2715-4505

Vol. 10 Nomor 02 Desember 2019. 87-93

yang hidup dalam masyarakat. Adapun rumusan masalah dalam penelitian ini adalah: Bagaimanakah Asas kepastian hukum berperan dalam penyelenggaraan perpajakan di Indonesia?

\section{METODE PENELITIAN}

Metode penelitian yang digunakan oleh penulis adalah yuridis normatif, dengan alat pengumpul data melalui studi kepustakaan yaitu studi dokumentasi peraturan perundangundangan serta artikel-artikel yang terkait dengan penelitian ini.

\section{PEMBAHASAN}

Menurut Hans Kelsen, hukum adalah sebuah sistem norma. Norma adalah pernyataan yang menekankan aspek "seharusnya" atau das sollen, dengan menyertakan beberapa peraturan tentang apa yang harus dilakukan. Norma-norma adalah produk dan aksi manusia yang deliberatif.Undang-Undang yang berisi aturan-aturan yang bersifat umum menjadi pedoman bagi individu bertingkah laku dalam bermasyarakat, baik dalam hubungan dengan sesama individu maupun dalam hubungannya dengan masyarakat.Aturan-aturan itu menjadi batasan bagi masyarakat dalam membebani atau melakukan tindakan terhadap individu.Adanya aturan itu dan pelaksanaan aturan tersebut menimbulkan kepastian hukum. Menurut Gustav Radbruch, hukum harus mengandung 3 (tiga) nilai identitas, yaitu sebagai berikutı :

1. Asas kepastian hukum (rechtmatigheid). Asas ini meninjau dari sudut yuridis.

2. Asas keadilan hukum (gerectigheit). Asas ini meninjau dari sudut filosofis, dimana keadilan adalah kesamaan hak untuk semua orang di depan pengadilan

3. Asas kemanfaatan hukum (zwechmatigheid atau doelmatigheid atau utility.

Tujuan hukum yang mendekati realistis adalah kepastian hokum dan kemanfaatan hukum. Kaum Positivisme lebih menekankan pada kepastian hukum, sedangkan Kaum Fungsionalis mengutamakan kemanfaatan hukum, dan sekiranya dapat dikemukakan bahwa "summum ius, summa injuria, summa lex, summa crux" yang artinya adalah hukum yang keras dapat melukai, kecuali keadilan yang dapat menolongnya, dengan demikian kendatipun keadilan bukan merupakan tujuan hukum satu-satunya akan tetapi tujuan hukum yang paling substantif adalah keadilan.

Menurut Utrecht, kepastian hukum mengandung dua pengertian, yaitu pertama, adanya aturan yang bersifat umum membuat individu mengetahui perbuatan apa yang bolehatau tidak boleh dilakukan, dan kedua, berupa keamanan hukum bagi individu dari kesewenangan pemerintah karena dengan adanya aturan yang bersifat umum itu individu dapat mengetahui apa saja yang boleh dibebankan atau dilakukan oleh Negara terhadap individu. Ajaran kepastian hukum ini berasal dari ajaran Yuridis-Dogmatik yang didasarkan pada aliran pemikiran positivistis di dunia hukum, yang cenderung melihat hukum sebagai sesuatu yang otonom, yang mandiri, karena bagi penganut pemikiran ini, hukum tak lain hanya kumpulan aturan. Bagi penganut aliran ini, tujuan hukum tidak lain dari sekedar menjamin terwujudnya kepastian hukum. Kepastian hukum itu diwujudkan oleh hukum

\footnotetext{
${ }^{1}$ Suwari Akhmaddhian, Asas-Asas dalam Penyelenggaraan Pemerintahan yang Baik untuk Mewujudkan Good Governace, Logika : Journal of Multidisciplinary Studies, ISSN 2085-9970. Vol. o9 Nomor o1 Juni 2018. 30-38.
} 
Logika : Journal of Multidisciplinary Studies, p-ISSN 2085-9970. e-ISSN 2715-4505

Vol. 10 Nomor 02 Desember 2019. 87-93

dengan sifatnya yang hanya membuat suatu aturan hukum yang bersifat umum. Sifat umum dari aturan-aturan hukum membuktikan bahwa hukum tidak bertujuan untuk mewujudkan keadilan atau kemanfaatan, melainkan semata-mata untuk kepastian.

Kepastian adalah perihal (keadaan) yang pasti,ketentuan atau ketetapan.Hukum secara hakiki harus pasti dan adil. Pasti sebagai pedoman kelakuan dan adil karena pedoman kelakuan itu harus menunjang suatu tatanan yang dinilai wajar. Hanya karena bersifat adil dan dilaksanakan dengan pasti hukum dapat menjalankan fungsinya. Menurutnya, kepastian dan keadilan bukanlah sekedar tuntutan moral, melainkan secara faktual mencirikan hukum. Suatu hukum yang tidak pasti dan tidak mau adil bukan sekedar hukum yang buruk, melinkan bukan hukum sama sekali. Kedua sifat itu termasuk paham hukum itu sendiri(den begriff des Rechts).Hukum adalah kumpulan peraturan-peraturan atau kaidah-kaidah dalam suatu kehidupan bersama, keseluruhan peraturan tentang tingkah laku yang berlaku dalam suatu kehidupan bersama, yang dapat dipaksakan pelaksanaanya dengan suatu sanksi.Kepastian hukum merupakan ciri yang tidak dapat dipisahkan dari hukum, terutama untuk norma hukum tertulis. Hukum tanpa nilai kepastian akan kehilangan makna karena tidak lagi dapat dijadikan pedoman perilaku bagi semua orang. Ubi jus incertum, ibi jus nullum (di mana tiada kepastian hokum disitu tidak ada hokum). Menurut Apeldoorn, kepastian hukum mempunyai dua segi. Pertama, mengenai soal dapat ditentukannya (bepaalbaarheid) hukum dalam hal-hal uang konkret. Artinya pihak-pihak yang mencari keadilan ingin mengetahui apakah yang menjadi hukumnya dalam hal yang khusus, sebelum ia memulai perkara. Ke dua, kepastian hukum berarti keamanan hukum. Artinya, perlindungan bagi para pihak terhadap kesewenangan hakim.

Menurut jan michiel otto, kepastian hukum yang sesungguhnya memang lebih berdimensi yuridis. Namun, otto ingin memberikanbatasan kepastian hukum yang lebih jauh. Untuk itu ia mendefinisikan kepastian hukum sebagai kemungkinan bahwa dalam situasi tertentu:

1. Tersedia aturan-aturan yang jelas (jernih), konsisten dan mudah diperoleh (accessible), diterbitkan oleh dan diakui karena (kekuasaan) negara;

2. Instansi-instansi penguasa(pemerintahan) menerapkan aturan-aturan hukum tersebut secara konsisten dan juga tunduk dan taat kepadanya;

3. Warga secara prinsipil menyesuaikan prilaku mereka terhadap aturan-aturan tersebut;

4. Hakim-hakim (peradilan) yang mandiri dan tidak berpihak menerapkan aturan-aturan hukum tersebut secara konsisten sewaktu mereka menyelesaikan sengketa hukum, dan;

5. Keputusan peradilan secara konkrit dilaksanakan.

Hukum yang di tegakkan oleh instansi penegak hokumyang diserai tugas untuk itu, harus menjamin "kepastian hukum" demi tegaknya ketertiban dan keadilan dalam kehidupan masyarakat. Ketidakpastian hukum, akan menimbulkan kekacauan dalam kehidupan masyarakat, dan akan saling berbuat sesuka hati serta bertindak main hakim sendiri. Keadaan seperti ini menjadikan kehidupan berada dalam suasana social disorganization atau kekacauan sosial. Kepastian hukum adalah "sicherkeit des Rechts selbst" (kepastian tentang hukum itu sendiri). Ada empat hal yang berhubungan dengan makna kepastian hukum. Pertama, bahwa hukum itu positif, artinya bahwa ia adalah perundang-undangan(gesetzliches Recht). Kedua, bahwa hukum itu didasarkan pada fakta (Tatsachen),bukan suatu rumusan tentang penilaian 
Logika : Journal of Multidisciplinary Studies, p-ISSN 2085-9970. e-ISSN 2715-4505

Vol. 10 Nomor 02 Desember 2019. 87-93

yang nanti akan dilakukan oleh hakim, seperti "kemauan baik", "kesopanan". Ketiga, bahwa fakta itu harus dirumuskan dengan cara yang jelas sehingga menghindari kekeliruan dalam pemaknaan, di samping juga mudah dijalankan. Keempat, hukum positif itu tidak boleh sering diubah-ubah².

Masalah kepastian hukum dalam kaitan dengan pelaksanaan hukum,memang sama sekali tak dapat dilepaskan sama sekali dari prilaku manusia. Kepastian hukum bukan mengikuti prinsip "pencet tombol" (subsumsi otomat), melainkan sesuatu yang cukup rumit, yang banyak berkaitan dengan faktor diluar hukum itu sendiri. Berbicara mengenai kepastian, maka seperti dikatakan Radbruch, yang lebih tepat adalah kepastian dari adanya peraturan itu sendiri atau kepastian peraturan (sicherkeit des Rechts). Berdasarkan paparan diatas, Apakah Hukum di Indonesia sudah menjamin adanya kepastian Hukum?. Banyaknya undang-undang yang dibuat oleh Dewan Perwakilan Rakyat (DPR) itu didasarkan atas kepentingan mereka dan Undang-undang itu dibuat bukan untuk kesejahteraan rakyat melainkan untuk keuntungan pribadi-pribadi mereka sendiri, oleh karena itu produk yang dibuat banyak yang tidak menjamin adanya kepastian hukum dan yang sungguh ironis adalah tidak ada Undangundang yang mensejahterakan rakyat. Indonesia dikenal dengan Negara yang Kaya, Negara yang letaknya strategis dan menjadi julukan sebagai Negara yang menjadi Jantung Dunia. Akan tetapi itu hanyalah sebuah cerita dongeng belaka karna kenyataanya adalah Banyak rakyat indonesia yang tidak merasakan Kekayaan Itu dan Bahkan mereka harus tidur dibawah jembatan dan banyak yang tidur di emperan toko. Itu semua disebabkan kesewenangan para pemimpin yang mementingkan diri sendiri ${ }^{3}$.

Banyak produk DPR yang menggambarkan bahwa hukum di Negara tercinta adalah hukum yang tidak menjamin adanya suatu kepastian. Sebagai contohnya adalah Undangundang Dasar 1945 amandemen Pasal 28D ayat (1) yang menyatakan bahwa setiap orang berhak atas pengkuan, perlindungan dan kepastian hukum yang adil serta perlakuan yang sama dihadapan hukum. Di sisi lain dalam Undang-undang Nomor 8 Tahun 1981 Tentang Hukum Acara Pidana pasal 14 butir b, yang berbunyi mengadakan pra penuntutan apabila ada kekurangan pada penyidikan dengan memperhatikan ketentuan Pasal 110 ayat (3) dan ayat (4), dengan memberi petunjuk dalam rangka penyempurnaan penyidikan dari penyidik. Dalam Undang-undang Nomor 8 Tahun 1981 Tentang Hukum Acara Pidana pasal 14 butir b, terdapat istilah pra penuntutan akan tetapi di dalam Bab I Ketentuan Umum pasal idan Penjelasan Umum Undang-Undang ini tidak dijelaskan atau terdapat istilah Pra penuntutan. Disini ada ketidak pastian mengenai apa yang disebut dengan Prapenuntutan.Apakah ini yang dibanggakan sebagai karya Agung anak Bangsa? Undang-undang yang dibuat pada tahun 1981 dan berlaku sampai sekarang ternyata tidak menjamin suatu Kepastian. Kenapa masih diterapkan dan digunakan? Dan kenapa tidak diganti dengan undang-undang yang lebih menjamin adanya suatu kepastian serta suatu keadilan?. Inilah suatu produk yang didasarkan atas suatu kepentingan dan pada ahirnya rakyatlah yang menanggung segala konsekuensinya dan rakyatlah yang menderita akibat perbuatan yang sewenang-wenang itu.

\footnotetext{
${ }^{2}$ Abustan, Relasi Lembaga Negara Dalam Perspektif Undang Undang Dasar Negara Republik Indonesia 1945, Jurnal Unifikasi, Issn 2354-5976, E-Issn 2580-7382 Vol. 04 Nomor 02 Juli 2017

${ }^{3}$ Asep Sukmawan. Kebijakan Pemerintah dan Hukum Pidana terhadap Pembangunan Listrik Tenaga Panas Bumi : Studi Kasus Padarincang, Banten. Logika : Journal of Multidisciplinary Studies, ISSN 2085-997o. Vol. o9 Nomor 02 Desember 2018. 57-64.
} 
Logika : Journal of Multidisciplinary Studies, p-ISSN 2085-9970. e-ISSN 2715-4505

Vol. 10 Nomor 02 Desember 2019. 87-93

Hukum harus pasti karena dengan hal yang bersifat pasti dapat dijadikan ukuran kebenaran dan demi tercapainya tujuan hukum yang menuntut kedamaian, ketentraman, kesejahteraan dan ketertiban dalam masyaraka serta kepastian hukum harus dapat menjadi jaminan kesejahteraan umum dan jaminan keadilan bagi masyarakat

Sudah umum bilamana kepastian sudah menjadi bagian dari suatu hukum, hal ini lebih diutamakan untuk norma hukum tertulis. Hukum tanpa nilai kepastian akan kehilangan kati diri serta maknanya, karena tidak lagi dapat digunakan sebagai pedoman perilaku setiap orang.Kepastian sendiri hakikatnya merupakan tujuan utama dari hukum. Apabila dilihat secara historis banyak perbincangan yang telah dilakukan mengenai hukum semejak Montesquieu memgeluarkan gagasan mengenai pemisahan kekuasaan.

Keteraturan masyarakat berkaitan erat dengan kepastian dalam hukum, karena keteraturan merupakan inti dari kepastian itu sendiri.Dari keteraturan akan menyebabkan seseorang hidup secara berkepastian dalam melakukan kegiatan yang diperlukan dalam kehidupan masyarakat.Menurut Sudikno Mertukusumo kepastian hukum merupakan sebuah jaminan bahwa hukum tersebut harus dijalankan dengan cara yang baik.

Kepastian hukum menghendaki adanya upaya pengaturan hukum dalam perundangundangan yang dibuat oleh pihak yang berwenang dan berwibawa, sehingga aturan-aturan itu memiliki aspek yuridis yang dapat menjamin adanya kepastian bahwa hukum berfungsi sebagai suatu peraturan yang harus ditaati. Lon Fuller dalam bukunya the Morality of Law mengajukan 8 (delapan) asas yang harus dipenuhi oleh hukum, yang apabila tidak terpenuhi, maka hukum akan gagal untuk disebut sebagai hukum, atau dengan kata lain harus terdapat kepastian hukum. Kedelapan asas tersebut adalah sebagai berikut :

1. Suatu sistem hukum yang terdiri dari peraturan-peraturan, tidak berdasarkan putusanputusan sesat untuk hal-hal tertentu;

2. Peraturan tersebut diumumkan kepada publik

3. Tidak berlaku surut, karena akan merusak integritas sistem;

4. Dibuat dalam rumusan yang dimengerti oleh umum;

5. Tidak boleh ada peraturan yang saling bertentangan;

6. Tidak boleh menuntut suatu tindakan yang melebihi apa yang bisa dilakukan;

7. Tidak boleh sering diubah-ubah;

8. Harus ada kesesuaian antara peraturan dan pelaksanaan undang undang

Pajak adalah iuran rakyat kepada kas negara berdasarkan undang-undang (sehingga dapat dipaksakan) dengan tiada mendapat balas jasa secara langsung. Pajak dipungut berdasarkan norma-norma hukum guna menutup biaya produksi barang-barang dan jasa kolektif untuk mencapai kesejahteraan umum.

Jadi, Pajak merupakan hak prerogatif pemerintah, iuran wajib yang dipungut oleh pemerintah dari masyarakat (wajib pajak) untuk menutupi pengeluaran rutin negara dan biaya pembangunan tanpa balas jasa yang dapat ditunjuk secara langsung berdasarkan undangundang. Dasar hukum sengketa pajak adalah sebagai berikut :

1. Undang - undang no. 14 tahun 2002 tentang pengadilan pajak.

2. Undang - undang no. 6 tahun 1983 tentang ketentuan umum dan tata cara perpajakan.

3. Undang - undang no. 16 tahun 2000, no 28 tahun 2007, dan peraturan pelakssanaan terkait. 
Logika : Journal of Multidisciplinary Studies, p-ISSN 2085-9970. e-ISSN 2715-4505

Vol. 10 Nomor 02 Desember 2019. 87-93

4. PASAL 1 angka 5 UU PP; Sengketa Pajak adalah sengketa yang timbul dalam bidang perpajakan antara Wajib Pajak atau penanggung Pajak dengan pejabat yang berwenang sebagai akibat dikeluarkannya keputusan yang dapat diajukan Banding atau Gugatan kepada Pengadilan Pajak berdasarkan peraturan perundang-undangan perpajakan, termasuk Gugatan atas pelaksanaan penagihan berdasarkan Undang-undang Penagihan Pajak dengan Surat Paksa.

Penyidik Direktorat Jenderal (Ditjen) Pajak pada Kantor Wilayah Banten pada tanggal 9 November 2015 telah menyerahkan seorang tersangka DP alias AK ke Kejaksaan Negeri Tigaraksa. DP alias AK merupakan komisaris PT SEP yang beralamat di Kabupaten Tangerang, disangkakan pada kurun waktu tahun 2012 - 2013 menerbitkan faktur pajak yang tidak berdasarkan transaksi yang sebenarnya dan menggunakannya dengan maksud mengurangi jumlah pajak yang harus dibayar oleh pengguna faktur pajak fiktif tersebut. Nilai kerugian Negara yang diakibatkan dari perbuatan tersangka tersebut diperkirakan sebesar Rpı,,6 miliar.

\section{SIMPULAN}

Hukum adalah suatu peraturan yang dibuat oleh lembaga yang berwenang untuk mengatur ketertiban masyarakat. Tujuan hukum yang mendekati realistis adalah kepastian hukum. Kepastian hukum adalah "sicherkeit des Rechts selbst" (kepastian tentang hukum itu sendiri). Suatu hukum harus pasti karena dengan hal yang bersifat pasti dapat dijadikan ukuran kebenaran dan demi tercapainya tujuan hukum yang menuntut kedamaian, ketentraman, kesejahteraan dan ketertiban dalam masyarakat serta kepastian hukum harus dapat menjadi jaminan kesejahteraan umum dan jaminan keadilan bagi masyarakat.

\section{SARAN}

Didalam penyelenggaraan pemerintahan tentunya harus diberlakukan asas asas pemerintahan yang baik (AAUPB), salah satunya asas kepastian hokum. Seperti pengertiannya sendiri asas kepastian hukum adalah adanya kepastian atau ketentuan hukum dari hukum yang telah dibuat dengan kata lain adanya sanksi dari pelanggaran hukum tersebut. Pemerintahan tentunya harus memberlakukan asas kepastian hukum dalam roda pemerintahanya,jangan sampai membuat masyarakat bertanya tanya akan hukum yang berlaku,dan jangan membuat masyarakat menunggu berjalanya hukum yang adil tanpa kepastian.

\section{DAFTAR PUSTAKA}

Abustan, Relasi Lembaga Negara Dalam Perspektif Undang Undang Dasar Negara Republik Indonesia 1945, Jurnal Unifikasi, Issn 2354-5976, E-Issn 2580-7382 Vol. 04 Nomor 02 Juli 2017

Asep Sukmawan. Kebijakan Pemerintah dan Hukum Pidana terhadap Pembangunan Listrik Tenaga Panas Bumi : Studi Kasus Padarincang, Banten. Logika : Journal of Multidisciplinary Studies, ISSN 2085-9970. Vol. o9 Nomor 02 Desember 2018. 57-64.

Suwari Akhmaddhian, Asas-Asas dalam Penyelenggaraan Pemerintahan yang Baik untuk Mewujudkan Good Governace, Logika : Journal of Multidisciplinary Studies, ISSN 2085-9970. Vol. o9 Nomor o1 Juni 2018. 30-38. 
Logika : Journal of Multidisciplinary Studies, p-ISSN 2085-9970. e-ISSN 2715-4505

Vol. 10 Nomor 02 Desember 2019. 87-93

http://windirahma25.blogspot.co.id/2016/o2/v-behaviorurldefaultvmlo.html

http://www.pajak.go.id/content/ditjen-pajak-serahkan-tersangka-kasus-penggelapan-pajakrp196-miliar-ke-kejaksaan 